\title{
Can Technology Bring Peace to The World?
}

Lilian Cusicanqui

Bolivia

Any sufficiently advanced technology is equivalent to magic.

Arthur C. Clarke

Technology and peace are terms that are now on everyone's lips. On one hand, technology and its development are fundamental to seek the welfare of society and the satisfaction of their needs; on the other, peace is one of the most abstract universal terms created by the human being, so subjective that it can englobe the absence of a war in a country to the personal fulfillment of a being. If we think for a minute the relationship they have, we can find out that with the right mindset and understanding technology can contribute to the real construction of a "Culture of Peace" (Hayashi, 2011).

Without wanting to sound drastically, we live in an accelerated society, based on individualism and dirty competition as defense elements in the face of dehumanization, in which the most important feature are "technological advances" that, that far from fulfilling their initial and main objective, end up separating people and the world of a life of happiness and social harmony as we can find many examples of it in the worldwide history (Duxbutry \& Smart, 2011).

Technological development goes hand in hand with the upward change of new social, political, economic, and cultural forms. All this represents a step forward for the world development yearned for. But satisfying at any price the objective and subjective needs of man, putting creativity to the limit and humangreed to dominate technological development (Kim \& Lee, 2020) at the expense of everything and everyone has become the central axis of the problem, the personal or political interests that surround technological innovation.

However, science and technology should not be the villains of history, but those people and powerholders who warn of these resources in search of satisfying their personal interests. It is necessary to shout that technology can do more than a product of destruction, lethal and massive; that technology means more than a parade of latest military tanks, biological, nuclear, and chemical weapons.

It is our personal, civil, and moral duty to spread and support advances that contributed and contribute to the harmonious human development. Such as the green technology that strives to achieve environmental-human sustainability, 
Vol. 2 - 2020

Universidad Privada del Valle - Bolivia

https://doi.org/10.52428/2788891.v2i2.49

medical technology in which each advance represents a decrease on the death rate worldwide, the development on physics that allow us to understand how the universe behaves and the rescue use of indigenous technologies as a symbol of our human self-knowledge.

It is time to revalue these kinds of te $\mathrm{chnologies}$ that achieved and will continue raising the quality of life of each of us. It is possible that with the correct mindset that all the advances lead us to a harmony advancement. We must not allow those technologies that already caused many deaths rob importance from those that have become a mean of peace, love, and life.

\section{REFERENCES}

Duxbury, L., \& Smart, R. (2011). The "myth of separate worlds": An exploration of how mobile technology has redefined work-life balance. In Creating balance? (pp. 269284). Springer, Berlin, Heidelberg.

Hayashi, R. (2011). Academic Sovereignty, Technology, and Soka Education: From a Culture of War towards a Culture of Peace. In 7TH ANNUAL SOKA EDUCATION CONFERENCE 2011 (p. 69).

Kim, J., Yoon, J., \& Lee, J. D. (2020). Dominant design and evolution of technological trajectories: The case of tank technology, 1915-1998. Journal of Evolutionary Economics, 1-16.

Fuentes de financiamiento: Esta investigación fue financiada con fondos de la autora.

Declaración de conflicto de intereses: La autora declara que no tiene ningún conflicto de interés.

Copyright (c) 2021 Lilian Cusicanqui

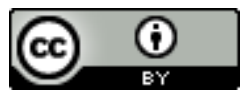

Este texto está protegido por una licencia Creative Commons 4.0

Usted es libre para Compartir — copiar y redistribuir el material en cualquier medio o formato — y Adaptar el documento —remezclar, transformar y crear a partir del material- para cualquier propósito, incluso para fines comerciales, siempre que cumpla la condición de:

Atribución: Usted debe dar crédito a la obra original de manera adecuada, proporcionar un enlace a la licencia, e indicar si se han realizado cambios. Puede hacerlo en cualquier forma razonable, pero no de forma tal que sugiera que tiene el apoyo del licenciante o lo recibe por el uso que hace de la obra.

$\underline{\text { Resumendelicencia - Textocompletodelalicencia }}$ 